\title{
Modern Store Regulation To Protect Traditional Market In Semarang
}

\author{
Paramita Prananingtyas \\ Faculty of Law \\ University of Diponegoro \\ Semarang, Indonesia \\ pptyas@yahoo.com
}

\author{
Fifiana Wisnaeni and Rahandy Rizki Prananda \\ Faculty of Law \\ University of Diponegoro \\ Semarang, Indonesia
}

\begin{abstract}
Modern market or modern store had a very important role in the economic growth in Semarang. The development of modern market that is uncontrolled and not pay much attention for the existence of traditional market is not good for the sake of fair trade practices towards domestic transaction in Semarang. The City of Semarang government had passed a regulation on modern store, the Regulation (Peraturan Daerah) no 1 year 2014 on Modern Store Regulation.
\end{abstract}

The paper is a research paper, the purpose of this research paper is to look at the implementation of Regulation (Peraturan Daerah) no 1 year 2014 on Modern Store Regulation and its implication toward fair trade competition between modern and traditional market. The methodology of this research is empirical legal research. It is also combining the regulation approach and inter-discipliner method. Primary and secondary data both are used in this research and analyzed by qualitative method.

The research finding are : 1 ) the regulation (Perda no 1 year 2014) ineffectiveness was affected by the legal weakness of the regulation and the inconsistence of the apparatus in applied the sanctions in any regulation infringements 2) investors of the modern store need to change their legal culture and their view of the legal structure of Semarang's investment regulation. This research also created some solution 1) amendment of the regulation especially article 8 of Perda no 1 year 2014, 2) rearrangement of modern store data collection among agencies and 3) moratorium application for modern store in Semarang.

This research is the first in the field of competition law, the originality of the research is on the primary and secondary data collecting.

Keywords : Modern Store, Traditional Market, Fair Trade Competition

\section{INTRODUCTION}

Retail industry is one of the most important industry in Indonesia emerging economy, it has a strategic and potential role. Indonesian government already excluded retail industry from the negative foreign direct investment list. This policy has its impact towards economic and legal growth of retail industry aggressively around Indonesia. It shown that the retail industry growth in some province and regions in Indonesia are less regulated and regardless of the store location with traditional market, the impact to fair competition is quite excessive.

The local regulation, Perda no 1 year 2014 on Modern Store Regulation and Mayor Regulation number 5 year 2013 on Modern Mini Market Regulation in Semarang City are the City of Semarang combined regulation in order to maintain the development and governance of traditional market, department store, supermarket and modern store growths and activities in Semarang. Both regulation are important because of its purpose is so much needed in order to maintain the fairness of trade between traditional market and modern market [1]

It is a duty of the government of Indonesia to pay a huge attention towards the greatest interest of the society including business people; because the government has an ability to create a competitive market for everybody. An accommodated policy based on a fair trade practices is very important. In order to reach those aim, the government of Indonesia has the ability to do an intervention in any business activities, thus a fair level of playing field will be created among business entities in Indonesia. Presidential Decree number 112 year 2007 on Regulation and Development of Traditional Market, Supermarket and Modern Store is a real example on the concern of Indonesian government towards a fair trade activities among business entities on retail industry. In that decree the traditional market are fully guaranteed and backed up by the government to still exist and growth in harmonize with the multinational supermarket / hypermarket and chain modern store.

Based on article 4 (2) of Mayor Regulation number 5 year 2013 on Modern Mini Market Regulation in Semarang City, at least 500 meter radius from a traditional market is very much needed to establish a modern store. But in reality many business people build their modern mini market in a radius less than 500 meter from the traditional market. Why is this phenomena still happening? This is quite interesting to be a subject of a research. The main purpose of this paper is the implementation of Perda no 1 year 2014 on Modern Store Regulation and its implication toward fair trade competition between modern and traditional market. This paper also will present a small solution on how to deal with modern store regulation in Semarang in order to preserve the existence of traditional market. 


\section{Method AND MATERIAL}

This paper was based on socio legal method of research. In this method an empirical legal method was applied combined with a research on regulation and legal concept. This paper also used combined social science method to analyze the legal phenomenon from the sociological view. To gather empirical data we do a depth interview towards several source / authority, such as the Office of Trade and Industrial of the City of Semarang; the Office of City Planning and Housing Development of the City of Semarang; The Indonesian Investment Coordinating Board of the City of Semarang; the Office of Mapping and Traditional Market Regulator of the City of Semarang; the business owner of modern market franchise and the chain owner of a modern market.

According to Jovanovich this paper is a research paper which is an evaluative paper because this paper will see whether rules or regulation are working for the practices of the governance of the traditional market and the modern store [2].

\section{LITERATURE REVIEW}

According to Kelly referring to Bolton paper predatory pricing is defined in economic terms as a price reduction that is profitable only because of the added market power the predator gains from eliminating, disciplining, or otherwise inhibiting the competitive conduct of a rival or potential rival. Stated more precisely, a predatory price is a price that is profit-maximizing only because of its exclusionary or other anticompetitive effects. The anticompetitive effects of predatory pricing are higher prices and reduced outputincluding reduced innovation-achieved through the exclusion of a rival or potential rival [3].

An OECD paper on predatory pricing analyzed that another recent phenomenon is the emergence of concern over non-price predation. Non-price predation, sometimes called raising rivals' costs, includes the abuse of judicial and administrative procedures to impede domestic and foreign competitors. Because the rules' against predatory pricing and dumping are natural weapons for the non-price predator, it is important that these rules be no broader than necessary; rules which are overbroad or imprecise invite their abuse for anticompetitive purposes. Non-price predation is not the only reason why predatory pricing rules must be carefully drawn; an imprecise rule carries real risks of costly errors. Mistaking competitive pricing as predatory will tend to inhibit price competition in the economy. On the other hand, mistaking predation for competition may foster higher prices from increased concentration in the long run. In light of these considerations, competition authorities should not take action unless the existence of predatory pricing can be established with a reasonable degree of accuracy and should recognize that it may be better to have no explicit rule prohibiting predatory pricing than to mechanically enforce such a rule [4].

A similar research on how a competitive action among retail industry has been written by Crasswell. According to Crasswell antitrust concerns arise from the response of conventional supermarkets to the entry of warehouse stores. While some supermarkets have responded by increasing the quality of their services, the most common response has been to reduce prices. Supermarket chains often cut prices only in the stores closest to the new warehouse store, a response known as "zone pricing." In some markets the warehouse stores continued to grow anyway. In Green Bay, warehouse stores captured thirty-three percent of the market within six months of their entry, and in Kansas City their market share is estimated at over fifty percent. In other markets, however, the supermarket price wars have forced the warehouse stores out of business or have caused the warehouse stores to abandon plans for expansion into neighboring markets. As a result, warehouse stores have attacked the price cuts by conventional supermarkets as being predatory [5].

In a research report conducted by Daniel Suryadarma, supermarkets have been around in Mayor urban centers in Indonesia for the last three decades. At the onset of the liberalization of the retail sector in 1998, however, foreign supermarket operators began entering the country, sparking fierce competition with local operators. Some corners claim that traditional markets are the real victims of the intense competition as they lose their customers due to the cheap, high quality products and the more comfortable shopping environment that supermarkets provide. Therefore, there are calls to limit the construction of supermarkets, especially in locations near traditional markets. In order to ensure a thriving traditional market environment, policies that will help to increase the competitiveness of traditional markets must be created and implemented. Firstly, improve the infrastructure in the traditional markets. This includes ensuring proper hygiene and cleanliness levels, ample lighting, and an overall comfortable environment. For example, the current two-story market building design is not popular among traders because customers are unwilling to go to the upper floor. In order to do this, local governments and private traditional market managers must go beyond considering traditional markets only as a source of income [6].

\section{RESUlt AND DisCUSSION}

After The birth of modern store around the City of Semarang is in consistent with the need of the society in the term of modern life. Most common are the need of a cheap bargain and completed goods sold in a very convenience ambient with air conditioned and self-service store. This changing of a life style is pushed the buyers from a traditional market to modern store / supermarket / hypermarket. In Semarang, the eagerness of buyers to visit traditional market was stunted by :

a) the traditional market physical condition, those market are dirty, not neat, undisciplined sellers and lacked of attention from the Office of Market Regulator on the market infrastructure (toilets; parking lot; waste disposal; security etc).

b) the amount of sellers are increasing without any consideration with the space for trading inside the traditional market, in this case the extra seller (the one without the ability to obtain a kiosk inside the market) will do the trading outside the market (nearby street or nearby neighborhood) 
c) problems in point $b$ above will lead to the advance problems such as traffic problem; social problems (criminals and beggars).

In the period of 2011 - 2016 the City of Semarang Government has already lessen some problems experienced by traditional markets, by implemented traditional market revitalization as the development priority under the RJPMD Kota Semarang 2011-2016 (Long Term Development Program for the City of Semarang Area, 2011-2016). During those periods the Office of Traditional Market Regulator has already repaired, improved and revitalized six traditional markets (Pasar Bulu, Pasar Rasamala, Pasar Sampangan, Pasar Jerakah, Pasar Peterongan, Pasar Pedurungan).

The competition between traditional market and modern store cannot be avoided. Since both type retailers had a difference style in business, it still possible that consumers of both retailer migrating from its original market, especially traditional market's consumers are migrating to modern store. There are two majors objective between traditional market and modern store, first is price, second is distance and third is comfort.

In theory, the modern store with its higher cost of operation such as tax, electricity, workers salary, its price should be more expensive than that in the traditional market. In reality that is not what happened, because the modern store prices could compete with the traditional market price. Even some commodities and products were sold cheaper in the modern store than in traditional market. Because of this price differential, customers and consumers preferred to do their shopping to the modern store instead of traditional market.

Distance and location are also important. Since the modern market owned by a big player in the field, they can choose a better location to established their chain store. Usually the chain modern stores are built near or in a residential area. Compared with traditional market which are built since the Old Regime Era, where the residential area are not as many as now. The traditional market with a less than 1 kilometer from a modern store will suffer a great impact, its income will decrease bigger in amount, compare with a traditional market that has more distance (1-2 kilometer) from a modern store.

Comfort is the last thing that important among consumers. Including into comforts are the ambience of the store, the ease of choose the displayed products, the affability and hospitality of the modern stores employee. In the traditional market the warmth and geniality comes from the bargain between seller and buyer. But among urban buyers, they are not interested on bargaining concept anymore, they need certainty and sureness in quality and quantity of goods.

The Government of the City of Semarang by enacted Regulation number 1 year 2014 on Modern Store Regulation had implemented some strategic system to control the competitive aspect between traditional market and modern store existence in Semarang. First is the zoning policy, second is licensing, third is time of open store and fourth is the quantity of modern store in the area.(The City of Semarang Regulation (Peraturan Daerah Kota Semarang) number 1 year 2014, 2014)
The zoning policy will regulate the specified zone or area for a specified use in the city area. The zoning policy will regard characteristic features and form of a certain zone into the need of the society. Into the zoning policy a modern store must considered the minimum distance (500 meter) with a traditional market or traditional retailers. Into the licensing policy, in the regulation it was said that to established a modern store, the owner must obtained a IUTM (modern store license) upon many licensing needed to set up a business in Semarang. Those licensing are quite difficult; long and worthy to be obtained at the Office of Investment Coordinating Board of Semarang. That is without reason, to prolong the mechanism is one of the idea of the Semarang Government to compound the rise of modern store. The City of Semarang called this policy a command and control approach to countervail the economic growth and development in the area. (The City of Semarang Regulation (Peraturan Daerah Kota Semarang) number 1 year 2014, 2014)

The regulation upon the time of operation for hypermarket, supermarket and department store is from 10.00 AM to 10.00 PM from Monday to Friday and 10.00 AM to 11.00 PM on Saturday and Sunday. For modern store the opening hours for business are 09.00 AM to 10.00 PM from Monday to Friday; 09.00 AM to 11.00 PM on Saturday and Sunday. This regulation has not regulate the 24 hours operation time for a modern store, but a discretion enacted by the Major of Semarang allowed the 24 hour business hours for modern store located in a main road. The maximum quota for a modern store in Semarang had not been regulated in the regulation, but according to the Mayor of Semarang regulation article 9 , maximum amount of modern store in all 16 districts (kecamatan) in the City of Semarang are 523 stores.("The Mayor of Semarang Regulation (Peraturan Walikota Semarang) number 5 year 2013.pdf," n.d.)

To implement the regulation, all of the business person engaging into the modern store business must complying with the regulation consistently. To uphold the regulation in order to control the growth of modern stores in Semarang, both office had to work in accordance. Those office are the Investment Coordinating and One Stop Services Board (BPMPTSP) of the City of Semarang and the Office of Trade and Industry of the City of Semarang.

According to Friedman, law by itself seldom solves problems; legal factors are secondary to social factors; law is a means in the larger culture, though within the legal culture it may be mistaken for an end. In his zeal to celebrate an "instrumental" view of law, he points out that " '[d]ue process' would be nothing, or nearly nothing, unless it produced due results"; but some lawyers think one of the reasons that due process is worth striving for is that it tends to produce due results, and some hold in addition the stronger opinion that in many areas of controversy we can reduce the risk of undue results better by insisting on due process than by focusing only on result .Some of the most interesting observations in the work concern questions of time and history [7].

This theory will lead us into the second theory by Chambliss and Seidman, according to this theory to view how the law works in the society we need to measure it through 
three elements. First is who held the responsibility to established the regulation? According to the Law number 32 year 2004 amended by the Law number 23 year 2014 on the Local Government, the City of Semarang Government has the ability to create and legislated a regulation. The City of Semarang Regulation was assigned by the Mayor of Semarang and then approved by the Legislative Council. This regional regulation cannot contradict with the Precidensial Decree number 112 year 2007 on Regulation and Development of Traditional Market, Supermarket and Modern Store. The second is who is going to uphold and applied sanction of this regulation. According to the empirical research done by this research, the Office of Trade and Industry of the City of Semarang will sanction any infringement of this regulation. Those sanctions are written notice to any modern store owners who infringed the regulation. If the infringement still continued or escalated into more action, the Office will suspended the license. And the final sanction is license revocation, by the Office of Trade and Industry of the City of Semarang in cooperation with the Office of the Investment Coordinating and One Stop Services Board (BPMPTSP) of the City of Semarang. The third measurement according to Chambliss and Seidman theory is how the society respond toward the regulation [8].

The Regulation (Peraturan Daerah) number 1 year 2014 and the Mayor Regulation number 5 year 2013 according to our research is not sufficient enough to protect the traditional market.

TABLE I. THE QUANTITY OF MODERN STORE BEFORE AND AFTER THE REGULATION NUMBER 1 YEAR 2014 ENACTED

\begin{tabular}{|c|c|c|c|c|}
\hline Year & $\mathbf{2 0 1 3}$ & $\mathbf{2 0 1 4}$ & $\mathbf{2 0 1 5}$ & $\mathbf{2 0 1 6}$ \\
\hline $\begin{array}{c}\text { Modern } \\
\text { Store Sum }\end{array}$ & 456 & 533 & 560 & 629 \\
\hline
\end{tabular}

It is showed that the modern store are growing rapidly after the Regulation number 1 year 2014 and Mayor Regulation number 5 year 2013 enacted. Many modern stores were constructed next to each other and very near, less than 500 meter from a traditional markets. The establishment of a modern store was also spreading across the City of Semarang regardless the measurement of the population of the area.

The most common infringement of both regulations are in the area of licensing policy. According to the Office of Trade and Industry of the City of Semarang only 239 modern stores had the IUTM (Modern Store License), 337 modern stores only has SIUP (Business Trade Lisence) and TDP (Company Registration Certificate).

Those infringement arose because 1) under article 8 of the Regulation (Peraturan Daerah) number 1 year 2014, to established a modern store does not need an analysis on social and economic impact of the modern store; 2) there is no strengthening of sanction from the regulators. The reason why those infringement arose because the zoning policy are frequently infringed and also the society tends to ignorance the slowly death of the traditional market.

\section{Conclusion}

1. To give a fair competition and also to prevail the existence of the traditional market against the modern market / modern store the Government of the City of Semarang had enacted the Regulation (Peraturan Daerah) number 1 year 2014 on Modern Store Regulation and the Mayor of Semarang Regulation number 5 year 2013 on Modern Mini Market Regulation in Semarang City. Unfortunately those regulation are not be able to prevent the rapid and massive growth of the modern market and modern stores in the City of Semarang.

2. The failed lay upon the legal structure of the regulation itself; the inconsistency of the bureaucrats bound in the law enforcement of these regulation and the lack of enthusiasm of the society.

3. Some alteration and amendment need to be done, first in the legal structure of the Regulation number 1 year 2014 especially article 8 . The coordination and data sharing among office in the City of Semarang need to be upgrade. Most important thing is the City of Semarang needs a moratorium on modern market.

\section{REFERENCES}

[1] P. Paramita and P. R.R., "Jurnal Ilmiah Implementasi Peraturan Daerah Kota Semarang No. 1 Tahun 2014 tetnang Penataan Toko Modern Terhadap Iklim Persaingan Usaha yang Sehat antara Toko Modern dan Pasar Tradisional di Kota Semarang," 2017.

[2] M. Jovanovic, "Legal Methodology \& Legal Research and Writing," 2012. [Online].Available:http://www.ius.bg.ac.rs/prof/materijali/jovmio/mei/Legal\% 20methodology $\% 20$ and $\% 20$ legal\%20research\%20and\%20writing.pdf. [Accessed 14 September 2017].

[3] M. Kelly, "Centre for Economic Research,"The Georgetown Law Journal, p. $88,2009$.

[4] O. "Predatory Pricing," [Online]. Available: https://doi.org/10.1097/PRS.0b013e3181c87aff.

[5] R. Craswell and M. R. Fatrik, Predatory Pricing Theory Applied : The Case of Supermarkets vs. Warehouse Stores, Yale, 1985.

[6] D. Suryadarma, "Competition Between Traditional Food Traders and Supermarkets in Indonesia," in Crawford Fund 2011 Annual Parliamentary Conference, 2011.

[7] L. M. Friedman, The Legal System : A Social Science Perspective, California: Russell Sage Foundation, 1975.

[8] J. Hagan and C. Shedd, "A Socio-Legal Conflict Theory of Preceptions of Criminal Injustice," University of Chicago Legal Forum, vol. 2005, no. 1, p. 8, 2005. 